\title{
The college English teaching model research based on cross-cultural communication
}

\author{
Rongjian Li \\ Jilin Animation Institute, Changchun, Jilin Province, China
}

Keywords: Cross-cultural communication, College English, English teaching, Model study.

\begin{abstract}
With the advancement of globalization, each country and culture under the background of the individual has carried out active interaction and communication, in this process, the main body of communication has become a college student. In the process of practical English learning, it is not just looking forward to apply it to understand each other's culture that needs in the process of actual communication more effectively cultivate cross-cultural communication ability.
\end{abstract}

\section{Introduction}

From China's reform and opening-up, the development of social economy has achieved remarkable achievement, which attracts a lot of international friends to this investigation, to facilitate the foreign friends to communicate Chinese culture as well as the development achievements, China is also a timely in the field of education to cultivate high quality and high professional talents and swaps [1]. Talent exchange also marked the cultural exchange between China and international has risen to a new level, so the Chinese college English teaching mode should be according to the actual need to reform the current social development and to promote the cross-cultural communication activities to get fast development of China [1].

\section{Cross-cultural communication analysis}

The characteristics of cross-cultural communication: First, the diversity of culture, countries with different culture is formed in the process of communication, cross-cultural communication is based on the communication with different countries culture under the premise of; Second, with common linguistic, i. e. , is the people of different languages in order to achieve the purpose of communication, application of the same kind can accept language to communicate with each other; Third, using oral direct expression characteristics, people often suffer in cross-cultural communication in communication takes the form of oral expression, and is directly face each other in communication.

Cross-cultural communication consciousness of the role of English teaching. The English name of "cross-cultural communication" is "cross - cultural communication (or Intel - cultural communication)". It refers to native speakers with the native language of communication between. It also refers to any in language and culture background differences of communication between people. Generally people think this refers to the native people in communicating with the native people should pay attention to because of the problems arising from different cultural background, how to communicate more smooth communication [1]. Cross-cultural communication ability is an important part of language communication ability, and cultivate the students' cross-cultural communicative competence is one of the tasks of college English teaching. "College English syllabus for college English teaching demand for cross-cultural communication ability training, think on cross-cultural communication teaching in college English teaching is necessary, the goal is to help students to solve in cross-cultural communication problems caused by cultural differences.

The significance and necessity of intercultural communication. Actual intercultural communication refers to the: between people of different language as well as the national language communication activities. People with different cultural backgrounds to communicate, you must use the language tool to complete [1]. Due to different countries all have their unique language features 
and properties, therefore, in order to achieve the mutual communication, is familiar with the national culture, on the basis of fusion with the cultural background of language to communicate, to produce more good effect. So in college English teaching should focus on the cultivation of the intercultural communication and application aspects.

Through the college English teaching can cultivate high quality English professional talents, so as to meet the needs of the cultural and economic communication among countries [2]. So, English professional talents should have good English communication skills, also need to be familiar with relevant national culture, and let this cultural infiltration to the actual language exchange. In training students' ability of intercultural communication, not only should emphasize students' learning in the traditional culture, and let the students be familiar with the relevant national language habits, lifestyles and ways of thinking, then, communication and learning stand in each other's point of view, in order to improve the effectiveness of cross-cultural communication. Learning in college English course will make students more detailed understanding of the relevant national traditional culture, and to extend, in order to realize the organic combination of classroom learning and practice activities, university teachers need to check before the class and collect information about the country's national characteristics, as of classroom teaching for the record [2]. To foreign culture melts into the university classroom atmosphere, make the college students in classroom English teaching practice could be carried out, which is beneficial to improve the student's ability of English practical application.

\section{Under the background of cross-cultural communication has advantages and disadvantages of the college English teaching}

If intercultural communication in the field of college English teaching reform to be successful, the college students is to get the English learning opportunities from the viewpoint of essence, in fact, English teaching does not require the use of a fixed mode, however, which contains the regularity of it is relatively easy to obtain, from the perspective of cross-cultural communication, teachers can use culture infiltration way to lead students to easily obtain the effective methods to learn English as well as one of the objective law, this method is more efficient than traditional teaching methods [2]. From another perspective, to achieve intercultural communication can enhance communication and understanding between teacher and students, promote the effectiveness of classroom interaction, and make teaching mode innovation.

Every coin has two sides, although the cross-cultural communication has more obvious advantages, however, this form of communication in China still has some deficiency, specific displays in:

Understanding of cross-cultural knowledge and English teaching are clear enough. At the request of the school, parents' expectations and the current social background, the purpose of teaching is considered to be let the children in the key moment of the tests or the entrance examination, to break through layers of high scores on top, into the school. Some teachers don't think it's time to teach the students what is cross-cultural designedly, and take the time to do [3]. Only talking about public class, the teacher will be considered to be in the form of what we expect or considered classroom, with students as the main body, there are interaction between teachers and students, theory with practice, the students spent in learning and happy. In fact from this point we can see, schools and teachers have realized the relationship between language and culture, but in the context of China's exam-oriented education, use too much time to teach is not the content of the examination scope is considered to be a waste of energy, schools need to graduation rates, and the parents need is high grade.

On the social history and culture of the target language countries lack basic knowledge. The history of a country is its language growth fertile soil, English is indispensable to the development of its land, the growth of English and its social culture, history and culture are closely linked [3]. Body language is primarily concerned with intercultural knowledge, but the teacher is to be done according to the text explanation, not out of the text to the students explain besides greeting knowledge of cross-cultural communication, such as Body language, table manners, material culture, etc.

Attitudes towards and acceptance of English cultural phenomenon lose weight. To reflect in the teaching of culture phenomenon, our middle school English teacher's attitude, embodied in the 
aspects: first, in view of the position of western culture is not objective. In content or in the classroom teaching of cross-cultural phenomenon or for, or meet some teachers to its deadweight, think that phenomenon belongs to foreign, not necessary to explain; some teachers' hazard guess its meaning. Second, the extreme attitude in terms of acceptance is western cultural differences [3]. Middle school English teaching materials to a certain extent reflects the culture of different things, including social customs and habits, values, etc. Middle school English teachers to these cultural differences show the different attitudes. Even for these different cultures show should not have stereotypes, such as the British and American people, asked her name, age, job, family. There are some teachers for the culture of English countries show attitude, think that as long as is the western culture is good, is worth learning and using for reference [4]. Teachers of English culture, influence students things to know, understand and accept the cultural differences, and it is values begin to form stage; middle school students are more conducive to their physical and mental growth.

Lack of training students' cross-cultural communication consciousness and ability of method and means. Curriculum requirements, in school and the teacher began to pay attention to foreign language teaching to the students' intercultural communicative awareness and ability, but in the specific operation of the teachers' lack of feasible method and means [4]. First law drab and inflexible, in the middle school English classroom, use in the output of the teachers as the main body, more students passively accept as the object of teaching, rarely more open, organizes the student to observe, discussion, exchange, take the student as the main body of teaching way, let them to go to their own form and social culture, to learn English is through simple description and interpretation of the teachers, the students understand the degree is limited. Secondly, the teaching material reflected in English-speaking countries for social and cultural phenomenon, ignore the contrast between east and west culture. We can use contrast teaching, active to let the students in teaching process to compare eastern and western culture, so that they will have interest to participate in and to get the conclusion of a sense of accomplishment, and strengthen their understanding of its culture and understanding of other cultures. Third, to the texts in the textbooks, teachers through a simple explanation, after that let the students read or recite enhancement language sense, this model under the education of students, ability to solve the problem, a high score, but communication ability is weak, can't combine theory and practice is very good, is not conducive to cultivate the students' cross-cultural communication consciousness and ability.

\section{Cross-cultural communication under the background of the right to build college English teaching mode}

Because the present Chinese college English education in intercultural communication situation showed more shortage, the continuing need for cross-cultural communication talents at the same time, makes the building of college English teaching mode has become inevitable, the response to cross-cultural communication is analyzed, and then understand the background of cross-cultural communication to create the opportunity and the challenge of college English teaching, then according to the outline about the college English curriculum requirements and planning outline of English multimedia teaching mode, under the background of cultural communication, trying to build for the purpose of cultivating college students' cross-cultural communication ability, can promote the basic teaching mode of college English teaching.

Make full use of existing books, newspaper, network resources such as learning English. Encouraged the students to put the books in the scene reappearance to the reality, and more close to life, to mobilize the students' interest in learning English, let them experience the foreign culture in the communication, and also exercise their English listening and speaking [5]. With the rapid development of science and technology in today's information age, a lot of good English learning resources for us to choose, broaden our vision about the western world. Make full use of the school introduced advanced network platform, it provides students with abundant resources of audio-visual, lets the student may at any time in their spare time watching or browse.

All kinds of racing etc activities, training students' English thinking ability. Many schools are held in the English speech contest, English debate on a regular basis, and some English drama 
performances in and outside class competitions [5]. Such competition way can stimulate students to English learning motivation, the process is to improve oral English, the students in the process is more or less understanding of cross-cultural knowledge, and the process itself is also in improving the students' intercultural communicative competence. That can meet the demand of students' individual character development, but also to cultivate students for English thinking ability, the ability to control.

A variety of cultural practice class activities, develop the students' ability of cross-cultural behavior. Schools can use local excellent education resources, interactive combined with local universities or colleges and universities, make full use of its powerful teachers, the foreign experts or lecturer please come into our school, the opening of a seminar on western culture, interact directly with students, build communication platform for the students, let them feel the authentic English and its ways and habits of speech [6].

In the long run, we learn English not only learning its language form, more attention should be paid to its rich content of the culture, this is our fundamental purpose of learning English, namely the cultivation of intercultural communicative competence [6]. We must expand the students' cross-cultural perspective, armed with good cross-cultural communication and the ability to communicate, to make it meet the need of modernization.

Solid language foundation seepage of cross-cultural knowledge. "Mother tongue refers to a person from prattles, from the first express ideas start using language. In most cases, the tongue is a person to use the most fluent language. In terms of cognition, language is a tool for all children know the world; in the aspect of culture, the language is the history and status of the expression of the most fundamental way. "in today's this big social background, the children almost began to contact the second language from kindergarten period, and kids this age have not certain cognitive ability, the most common is the confusion between Chinese pinyin and English letters [6]. In junior middle school stage, the children have taken a few years of English learning, people take it for granted that students can easily accept the all England teaching, but only a few students can do it and achieved excellent results, most cannot do. The basis of language determines the students' ability of learning a second language. In the middle school stage, for more complex articles or in the introduction of western culture, we can appropriate use of mother tongue to explain, lets the student in understanding from the obstacle under the premise of learning the culture. It can enhance their interest in learning, so that they are listening to the English due to not understand tired of emotions.

The second classroom, multi-channel training students' cross-cultural communication ability. China's ministry of education promulgated the new "high school English curriculum standard" requirement stage of course mission is: "to inspire and cultivate students' interest in learning English, make students build self-confidence, develop good study habits and effective learning strategies of cooperation, the development of autonomous learning ability and the spirit of cooperation, forming a certain comprehensive language using ability, for their lifelong learning and development to lay a good foundation. "In addition to learning English exams, should also pay attention to cultivate students' comprehensive ability [7]. Due to our current examination system comparison pay attention to the classroom teaching, while ignoring some extracurricular activities, is considered to be no time and energy. Thus hindered the all-round development of students, reduce the students' own initiative to explore and practice ability. So we're going to find students' interest in study, return the second classroom. Colorful second class, not only can cultivate their awareness of autonomous learning, cooperative learning ability, also can be active to find problems, start work ability to solve problems, to utter exercise their listening and speaking skills, so as to fully improve.

Consolidate classroom knowledge, broaden the classroom culture knowledge. When developing the second classroom activities, to achieve a better teaching effect, generally take a combination of inside and outside of class, knowledge related to the course content, Robinson and his friends, Friday, for example, it is a very short articles, but in the second class we can bring the book into, collective discussion, let the students discuss the social background and the protagonist of the importance of perseverance and friends, and so on [7]. So they did saying say brain thinking, to broaden the horizons, experience the cultural connotation of the novel and enjoy it. 
Make full use of multimedia, create a relaxed learning atmosphere. We can make full use of electronic equipment, for the students to enjoy the film or song, etc [7]. The famous Chinese think of the language, practice the real spoken English is the best way to look at British and American film and television, the premise is problems of some task-based group discussion, solve the problem in a relaxed conversation, also let them learn easily in the multimedia teaching different, and the application of tone of voice, Britain and America in this respect, more can exercise the students' listening and speaking skills, make them feel what is idiomatic English, Anglo-American culture at the same time they can have an intuitive feeling and visual impact. This for our teachers and students is a big advantage.

\section{Summary}

Language belongs to a kind of tool of human communication; it can be achieved in People's Daily lives between people exchanges. Before language culture, and language is an organic part of culture, language and culture represents about ethnic characteristics, due to the language belongs to a kind of important tool of human communication, so the application of cultural knowledge level becomes more important ability. On behalf of the cross-cultural communication is in the nature of different social and economic background, the people of the respective cultural background and language habits, using language to communicate both sides can accept. Communicate, must, in accordance with the relevant provisions of the principle of communication, this kind of communication can also be a cross-cultural communication ability, can use their own communication skills both in communication, in the communication process build a more harmonious relationship.

\section{References}

[1] W. Zh. Wu, The communication between different cultures and foreign language teaching, Foreign language teaching and research, 2015, vol. 4, pp. 23-27.

[2] J. T. Liu, Language and cultural relations, Foreign language study, 2010, vol. 5, pp. 37-41.

[3] Q. Y. Liu, Talking about cross-cultural communication in English teaching, Journal of Liaoning institute of education administration, 2006, vol. 10, pp. 33-35.

[4] X. L. Liu, The cultivation of college English teachers' intercultural communication research, Education and occupation, 2009, vol. 32, pp. 49 -50.

[5] T. T. Wei, Look from the cultural conflicts in cross-cultural communication in English teaching ability, Liaoning institute of administrative proceedings, 2006, vol. 6, pp. 159-162.

[6] Y. T. Wang, Intercultural communication for the purpose of foreign language teaching, Beijing language and culture university press, 2005, vol. 5, pp. 67-71.

[7] X. H. Zhang and J. H. Cai, Theory of the role of cultural factors in foreign language practice ability, Journal of Jilin institute of education, 2007, vol. 23, pp. 79-80. 